\title{
News From the Field
}

\section{G R A N T S}

- A grant of $\$ 125,000$ has been awarded by the Andrew W. Mellon Foundation of New York to the Toronto School of Theology, a federation of seven theological colleges and faculties in Toronto. The grant will defray the cost of microfilming the existing library shelflists of two of the participating TST schools which are not on the University of Toronto campus, Regis College and St. Augustine's Seminary, and the cost of editing these records for inclusion in the University of Toronto library's Campus Union Catalog which already records the holdings of the other five theological schools. Microfilming of the two shelflists was completed early in the summer, and it is expected that the editing will be completed in the spring of 1975.

Concurrently with this special grant-supported project, the Regis and St. Augustine's libraries have begun to report their new accessions to the Campus Union Catalog on a regular basis as do the other on-campus libraries. Thus, the Union Catalog will become the central source of information about theological library collections in the University of Toronto and the two outlying locations. Together, these collections are the most important in Canada and contain many items valuable for research.

- The University of Richmond is committing $\$ 100,876$ toward improving the partnership between its faculty and library staff during the next five years with the help of a $\$ 50,000$ grant under the joint College Library Program of the Council on Library Resources (CLR) and the National Endowment for the Humanities (NEH). The program's broad goal is the enhancement of the college library's role in the education of undergraduates.

In its "Library-Faculty Partnership" program scheduled to begin in September, major cooperation between Richmond undergraduate faculty and library staff is the key ingredient for broadening the library's use and usefulness. Three or four faculty members in the humanities and social sciences will be selected each year to devote half their time to specific libraryteaching duties under the supervision of the university librarian. Such duties will include: the development of library-centered teaching, the provision of assistance in reference services, development of a program of instruction in the use of the library, and the planning and inauguration of a ten-year collection development program. A new library staff position, director of collection development, will be created under the five-year program. Student assistants will also be assigned to the program.

- Brown University, the recipient of a CLR-NEH grant, is beginning its fourth year of a program improving library service for undergraduates through the use of intensively trained graduate student advisors from various disciplines. As more Brown undergraduates undertake individual reading and research projects, they require more specialized assistance than regular librarians might ordinarily supply.

Eight graduate students were chosen the first year. They were trained intensively in reference work for the months of July and August. The second and third years ten students were chosen. The first month of training is rigorous. The graduate students work full time, seven and a half hours a day. They learn reference techniques by rotating through each of the eight library departments, and by filing, searching, and

\section{NEW FEATURE IN SCHOOL MEDIA QUARTERLY}

School Media Quarterly is interested in initiating a feature entitled "School Media Dissertations in Progress." This will be a part of SMQ's Current Research column and will appear in each issue of the journal. Media has been identified for this listing as any print or nonprint aid to instruction from preschool through secondary education. SMQ's interest includes the history, design, production, testing, use, organization and evaluation of media and media centers.

The listing in "School Media Dissertations in Progress" will include: (1) researcher's name; (2) proposed dissertation title; (3) school accepting the dissertation proposal; (4) date proposal was accepted; (5) anticipated date of completion and (6) name of major advisor.

Any reader of CRL News who is involved in such a study, or knows of someone so involved, is asked to contact SMQ's research editor supplying as much of the above information as possible. This contact would greatly assist in establishing the feature. Contact: Carl T. Cox, Research Editor, School Media Quarterly, 804 Volunteer Blvd., Knoxville, TN 37916. 
No mistake. Dewey System libraries now have access to the world's largest private collection of authoritative catalog records. That's because Richard Abel \& Company's entire data base of over 610,000 catalog records is now available with Dewey classification as well as L.C. The records include English language titles, 38,000 foreign records, new and retrospective titles, and titles listed in BCL, BJCL and other important bibliographies. And besides this, we have a continuing program of updating these records with over 2500 new titles each week from MARC tapes, NUC, and our own original cataloging

The Richard Abel Dewey Plan now offers libraries opportunities never before available:

- An unprecedented number of authoritative records to select from.

- Your choice of any combination of acquisitions, cataloging and complete book processing services

- Some quick and easy ways to order cataloging and processing to your specifications.

- The opportunity to save time, money, and reduce your paperwork to an absolute minimum.
We'd like to show you how we've made the Dewey System 610,000 times better. And if you are considering changing from Dewey to $L$. C. we'd like to show you how easily it can be done Just phone 800-547-3551 toll free, or mail the coupon.

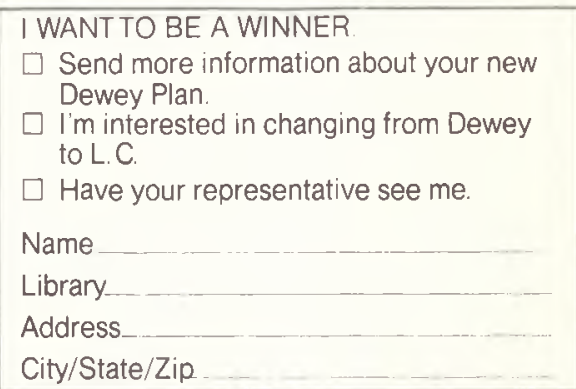

\section{Richard Abel \& Company, Inc.} P.O. Box 4245/Portland, Oregon 97208 (503) 645-3511/Telex 36-0458

OFFICES IN: Mill Valley, Ca. $\bullet$ Los Angeles • Denver • Dallas Kansas City, Mo. - Zion, III. - Marion, Oh. - Nashville. Tn. Atlanta, - Washıngton, D C - Blackwood, N J. - Newton Centre, Mo - Toronto - London - Amsterdam - Melbourne Sao Paulo. 
working at the desk. During the second month, the graduate students rotate between desk duties and research work in library sciences. They receive no academic credit for their work, but they are allowed a $\$ 3,000$ stipend and tuition may be remitted in some cases. After the library training of the graduate student is completed, he must give fifteen hours a week to the program. Nine of the hours are desk work, during which the student is available for consultation. The remaining six hours are spent doing liaison work with the academic department of his specialty.

- A $\$ 28,000$ grant for a project to be undertaken jointly by the Ellen Clarke Bertrand Library and the Freas-Rooke Computer Center has been awarded to BuckNell UNIVERsity by the Council on Library Resources. The grant is for support of work on an automated on-line retrieval system in the library.

The retrieval system is one aspect of an effort to automate many of the services in the Bertrand Library. This automation will provide better service to users of the library by allowing them immediate access to certain records and will permit the librarian to plan more intelligently for long-range goals and to utilize human resources to greater advantage.

The project involves storing on computer discs the complete call number, author, title, and publication date of the more than 200,000 titles in the library. This will add approximately 40 million characters to those stored on the university's central computer system. Computer programs will then be designed and written to permit any user of Bucknell's time-sharing computer system to search out instantly the stored information in a variety of ways. Eventually, the project may include an expansion of the data base to include more information on each volume and to include information on periodicals, serials, and other library collections. The results of the project, when completed, will help to define more accurately whether a library, serving primarily undergraduates, can improve its services with the aid of a computer.

\section{G I F T S}

- The Cleveland Public library was recently bequeathed a collection of original material on motion pictures from the estate of the late W. Ward Marsh, former film critic for The Plain Dealer. His files, amounting to a personal library of material dealing with the production, promotion, and criticism of films as well as the personalities of Hollywood, were accumulated and organized by Mr. and Mrs. Marsh during his fifty year career at the newspaper. Officially titled the W. Ward Marsh Cinema Archives, these papers will be incorporated into existing files now maintained in the Theatre-Cinema Collection, a division of the Main Library's Literature Department.

The major categories of the bequest are: production stills which begin with the films of the Thirties and concentrate on those of the Forties and Fifties; an actor/actress file of folders for individual personalities containing studio and agent biographies, clippings and publicity photos; "pressbooks"-kits of advertising materials used for promoting a specific movie; a review file numbering over 20,000 critiques clipped from Boxoffice, Variety, and miscellaneous trade journals which include a record of each of Marsh's own reviews; and his correspondence.

Also included are a specially bound copy of the shooting script (accompanied by color transparencies) for Cecil B. deMille's remake of The Ten Commandments; and a collection of more than seven hundred 4 by 5 -inch glass slides-dating from the silent era-which were used by theatre owners to promote their upcoming attractions.

\section{MEETINGS}

Nov, 11-14: CATV and Irs Implications FOR Libraries. To be held at Allerton House, Robert Allerton Park, University of Illinois Conference Center, Monticello, Illinois. Co-sponsored by Illinois State Library and The University of Illinois Graduate School of Library Science, and The Division of University Extension. Additional information may be obtained from: Leonard E. Sigler, Institute Supervisor (OS-89), 116 Illini Hall, Champaign, IL 61820.

Nov. 17-18: The Corporation of Professional Librarians of Quebec will hold its fourth annual meeting at the Auberge des Gouverneurs, Québec City. Featured will be a study on the delimitation of professional tasks vis-àvis the tasks of other library personnel.

Nov. 28: The New England College and Research Librarians, a chapter of ACRL, will present a program on "Faculty Status for Librarians," to discuss ACRL's program in academic status and the Harvard guidelines for academic librarians. The program will be held at the M.I.T. Faculty Club in Cambridge, Massachusetts. A social hour at 5:00 p.m. will be followed by dinner at 6:15 and the program at 7:15. For further information, contact Thomas H. Cahalan, assistant librarian for acquisitions at Northeastern University in Boston.

Nov, 28-30: Using Information Services, A two-day seminar (with an optional third day) on using information sources and services, 
to be held November $28-30,1973$, has been announced by the National Federation of Abstracting \& Indexing Services. The host institute is Pratt Institute-Graduate School of Library and Information Science, and the seminar will be held at the Pratt Manhattan Center in New York City. For further information see the October News.

Nov. 30-Dec. 1: Federal Documents Wonкsнop. This regional workshop is intended for librarians from Federal Region V (Illinois, Minnesota, Wisconsin, Indiana, Ohio and Michigan). The possibility of librarians and others from outside this region is not entirely excluded but in the final registration preference will be given to the persons from Region $\mathrm{V}$ if necessary. The workshop is one of a series sponsored by the Government Documents Round Table of the American Library Association. For further information see the October News.

Dec. 13-14: Library Instruction. The University of Denver will be sponsoring a conference on the evaluation of library instruction. Persons wishing conference information should contact Richard J. Beeler, reference department of Penrose Library, University of Denver, University Park, Denver, CO 80210.

\section{MISCELLANY}

- Druny College has recently issued a pocket guide to the Walker Library. A limited number of copies are available without charge by sending a stamped, self-addressed envelope to Paul Duckworth, Drury College, Springfield, MO 65802 .

- The Hertz Classical Library at the University of Virginia has received no published notice since 1913. This note reviews briefly the history of the library, its organization, and peculiar cataloging problem.

Professor Martin Julius Hertz (1818-1895), a German classical philologist, was distinguished as a grammarian and textual critic. The Hertz Library is the private collection of Martin Hertz and includes some 13,000 volumes and pamphlets, some of which are carefully annotated by Hertz and contemporary classical scholars. Shortly after Hertz' death, the University of Virginia Alumni purchased the library to replace the many valuable books burned in the Rotunda fire (1895).

After eighty years, the bound volumes and periodicals of the Hertz Library have finally been cataloged. Most of these are kept in the General Collection of the Alderman Library. The more valuable books, such as Aldine and Elzevir imprints, are kept in the Rare Book Department. Also in Rare Books is a substantial archive of German dissertations in pamphlet form which remains uncataloged. These dissertations have been organized in boxes by subject, and await the trained hand of a scholarlibrarian who has not only a fair knowledge of classical literature and civilization, but an excellent (preferably native) understanding of the German tongue.

Cataloging the Hertz pamphlets has been a low-priority project for as long as the collection has been at Virginia. It is believed, however, that with the possible exception of the Princeton archive, the Hertz pamphlets may be the finest collection of nineteenth century German classical dissertations in this country. Certain items may well be unique.

Since money is unavailable for cataloging the Hertz pamphlets, the library hopes to attract an interested person who would produce a cata$\log$ as a thesis or dissertation.

- The Gax Academic Union, a group of men and women including teachers, researchers, artists, graduate students, librarians, and administrative personnel, has been formed in New York City and is now holding regular meetings. The group, which is open to all concerned persons, has as its avowed general purpose the liberation of gay people in the scholarly and teaching communities of the United States and undertakes specifically: 1. to oppose all forms of discrimination against gay people within academia, 2, to support individual academics in the process of coming out, 3 . to promote new approaches to the study of the gay experience, 4 . to encourage the teaching of gay studies throughout the American educational system.

The committees of the Gay Academic Union formed thus far include Study, Communications, Finance, Academic Freedom, and Conference. The function of the Conference Committee is to plan the first Conference of Gay Scholars, to be held in New York City over the Thanksgiving weekend, November 23-24, 1973.

For membership information in the Gay Academic Union, contact Professor K. S. Sherrill, Department of Political Science, Box 1479, Hunter College, C.U.N.Y., 695 Park Ave., New York, NY 10021.

- The American Library Association has been awarded a fourteen month contract by the National Center for Educational Statistics, U.S. Office of Education, to design an operational handbook to accompany the new federal-state system of collecting basic Library Statistics. Project director for the contract is Robert W. Frase, economist and formerly vice-president and economist for the Association of American Publishers. The project coordinator is Dr. Barbara Slanker, director, ALA Office for Research, Chicago. 
The project calls for the revision and expansion of the 1966 ALA publication Library Statistics: A Handbook of Concepts, Definitions, and Terminology. To be published by the Office of Education and distributed by the Superintendent of Documents, the new handbook will form an essential base for the Library General Information Survey (LIBGIS), a projected system of collecting statistics from all types of libraries developed by the National Center for Educational Statistics.

Type of library activity and the use to be made of library statistics will be emphasized in the new handbook. It is anticipated that the revised handbook will consist of four principal sections: statistics of libraries; statistics of federal, state, and regional library development agencies; statistics of library education; and a glossary of terms. The section on statistics of libraries will include: library resources (print and nonprint materials and equipment), library finance; library personnel, technical services; physical facilities; and library use. Ten to twelve consulting specialists will be retained to prepare the chapters of the handbook. For further information write or call Barbara Slanker (312) 944-6780 or Robert W. Frase (202) 265-5576.

- Now available to ARL Member InstituTrons from Systems and Procedures Exchange Center are goals and objectives statements from twenty-one ARL libraries. The statements fall into five broad categories: comprehensive, detailed analyses, including mission statement, overall objectives, and performance goals (e.g., Columbia, Cornell, U. Illinois); statements of mission and overall objectives (e.g., Iowa State, Rutgers, U. Connecticut); statements of mission and objectives included as part of legislation enabling documents (e.g., National Library of Canada, National Library of Medicine); statements of short-term performance goals (e.g., Florida State U., Ohio State U.); statements included as part of an overall planning document, budget document, or annual report (e.g., U. of California, Davis, New York State Library, U. of California, San Diego ).

While these documents do not normally include an account of the circumstances leading to their formulation, the process of formulation, or the manner in which they are used, they do provide examples of the kind of objectives statements that have been developed to provide direction to research libraries' activities.

In addition to these statements of goals and objectives, the SPEC files include annual reports from forty-three ARL libraries, and organization charts from forty-six. As with the objectives statements, these are available to SPEC participants upon request: annual reports on loan; copies of organization charts for retention.
- Two librarians at Califoria State UnivERSITY in Los Angeles are setting up a volunteer Task Force to index HERSTORY, the microfim collection of women's periodicals published by the Women's History Research Center in Berkeley, California. The Women's History Research Center is a nonprofit organization which incorporates the Women's History Library and the International Women's History Archives.

HERSTORY is a one-of-a-kind collection. In order for it to be better utilized now and in the future and because of its immense historical value, it must be subject-indexed. Librarians who are willing to devote three to five hours weekly for a period of three months to index one reel of the 23-reel microfilm collection should write directly to Jean Barnett, and Ann Pettingill, Reference Department, JFK Memorial Library, California State University-Los Angeles, 5151 State College Dr., Los Angeles, CA 90032 .

- A Commission on Documentation in the Anthropological Sciences was formed during the meeting of the ninth International Congress of Anthropological and Ethnological Sciences, held in Chicago, August 28-September 7, 1973. Hans E. Panofsky, curator of the Melville J. Herskovits Library of African Studies at Northwestern University and chairman of the Anthropology Section of the Association of College and Research Libraries, was named chairman of the commission.

The commission presented the following motion which was adopted by a plenary session of the congress:

It is the consensus of this Commission that existing resources for the bibliographical control of anthropological data are inadequate for indepth research on a disciplinary, regional or cross-cultural level.

Good bibliographies exist for some general and regional areas; but many of these are limited or not geared to anthropological research, omitting pertinent materials. In view of this requirement, the Commission proposes to establish three ongoing operations.

1. A clearinghouse which will function as a center for a communications network among participating members and other interested parties.

2. A committee to survey the adequacy of existing bibliographic resources of relevance to all anthropological sciences.

3. A committee to formulate standards for a comprehensive bibliographic system which will meet the requirements of anthropological sciences. 


\section{At last, one source of subject access to $20 t$}

\section{CUMULATIVE MONTHLY}

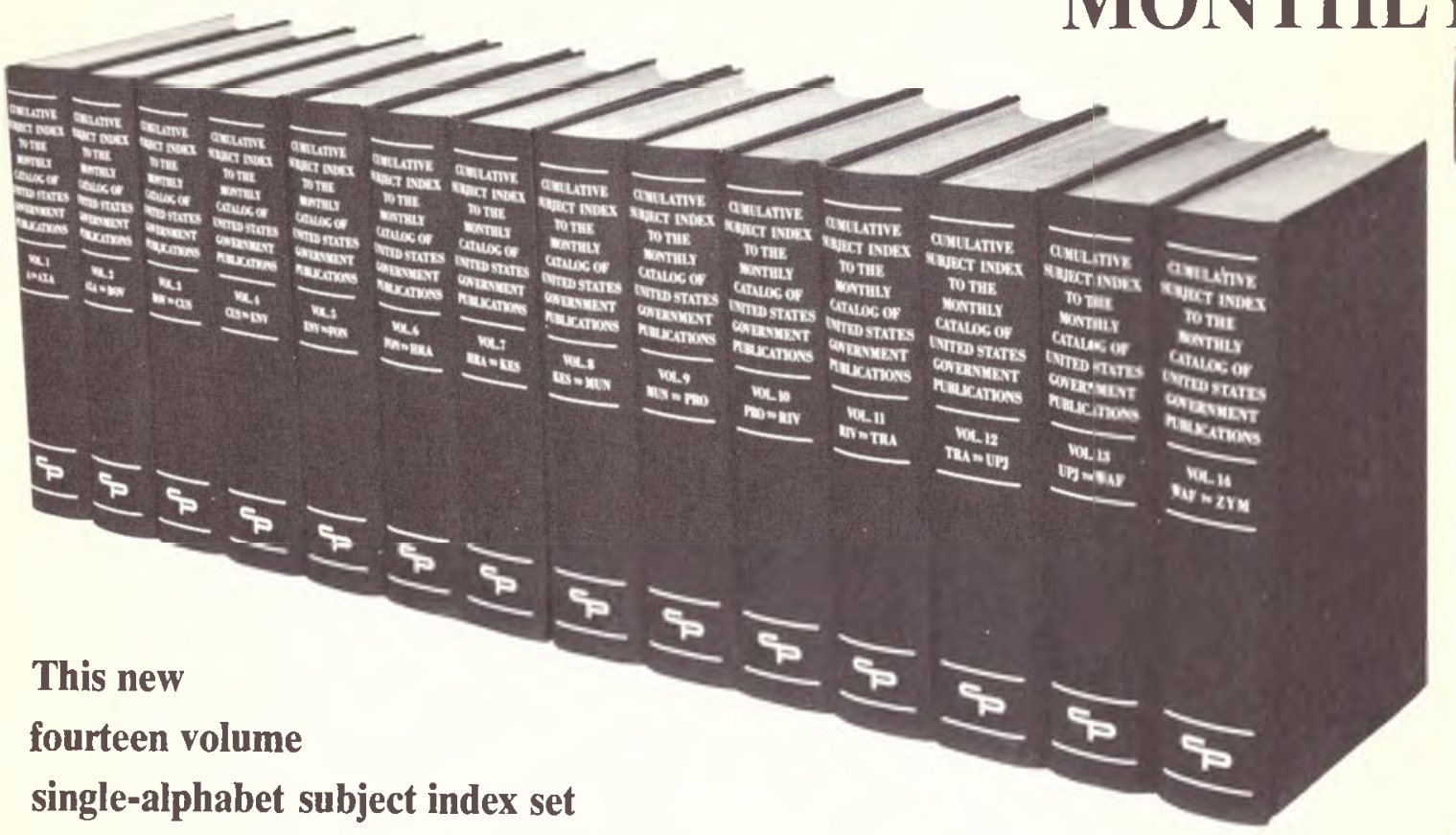

... is offered by itself - for libraries holding complete runs of the Monthly Catalog — or, in a

\section{COMBINED REFERENCE EDITION}

which contains a complete MICROFILM collection of the Monthly Catalog from 1895 through 1971 for convenient reference use with the index volumes.

The complete backfile of the Monthly Catalog was microfilmed by the Photoduplication Division of the Library of Congress especially for use with our Cumulative Subject Index. The 53 reel set contains the full text of all 867 indexed issues of the Montlly Catalog and its 3 World War II supplements, plus the two Decennial Indexes, and some 60 pre-1900 issues which were not indexed.

Monthly Catalog entries contain complete bibliographical data for almost every U.S. Government publication; including title, personal author, collation, LC number, SuDocs classification number, price, ordering information, and a symbol indicating if the publication was sent to depository libraries.
All Subject Index entries before September 1947 show year-and-page numbers whereas later entries give yearand-entry numbers. Each two digit year number ('00 through '71) serves as the reel number in the microfilm collection. Page and entry numbers appear in numerical sequence on the film; and as all entries for any given year of Monthly Catalog are on the same reel, the numerical sequences are never broken and it is never necessary to look on more than one reel for any single year.

Because of the lack of standardization in the microfilm industry, we offer our sets with a variety of film options; including a choice between silver halide film or Diazo, roll or cartridge, and $16 \mathrm{~mm}$ or $35 \mathrm{~mm}$ film size.

Note: Although we believe the Combined Reference Edition concept described above is a most efficient yet inexpensive system, the Cumulative Index Volumes can also be used effectively with sets of the original Monthly Catalogs, or with other microfilm versions of the series. Libraries having incomplete collections of the Monthly Catalog can, of course, complete their holdings with the purchase of microfilm reels for individual years. 


\section{h Century U.S. Government Publications}

\section{SUBJECT INDEX TO THE CATALOG OF UNITED STATES GOVERNMENT PUBLICATIONS 1900-1971}

"In this ambitious new library tool, cumulative access is brought for the first time to the overwhelming majority of United States Government publications issued during the period 1900-1971. "In this, it is an accomplishment unrivaled in size and scope. "Documents librarians will find it a new and convenient time-saver and one which should offer them an additional means of providing an expanded and improved Government publications service to their patrons."

From the Foreword by Carper W. Buckley, United States Superintendent of Documents, 1952-1970

The unique new CUMULATIVE SUBJECT INDEX will eliminate 34 search steps which were formerly necessary to trace subjects through these indexes to 20 th Century U.S. Government publications:

-21 Biennial Document Catalogs (1900-1940),

- 2 Decennial Indexes (1941-60), and

-11 Annual Indexes (1961-1971).

All subject entries in the fourteen volume cumulative index were accumulated from 81 separate sources in the $M o n t h l y$ Catalog series and merged into one reference set. These sources include: 48 Annual Indexes to the Monthly Catalog, 2 Decennial Indexes, (1941-1950; 1951-1960), 1 Six-month Index, and 30 Monthly Catalogs for which no annual indexes were made.

Delivery: The complete microfilm segment and Index Volumes I (A-Ashworth) and II (Asia-Canacao) are available for immediate delivery, and the remaining volumes are scheduled to follow at decreasing intervals until the projected completion date of May 31, 1974. Meanwhile, all Monthly Catalog indexes and the 2 Decennial Indexes on microfilm are included in the microfilm segment for temporary use.

USE THIS COUPON TO RESERVE YOUR SETS AT PRE-PUBLICATION PRICES

To: Carrollton Press, Inc.

1647 Wisconsin Avenue, N.W., Washington, D. C. 20007

Please record our order for the following:

The complete COMBINED REFERENCE EDITION containing:

1. Cumulative Subject Index to the Monthly Catalog of United States Government Publications, 1900 1971 , in 14 hardcover volumes, and

2. the full text of the Monthly Catalog of U.S. Government Publications, from 1895 through 1971, plus three World War II Supplements, and two Decennial Indexes, all on 53 reels of $16 \mathrm{~mm}$ silver halide microfilm.*

Note: Purchase of the Combined Edition results in a savings of $\$ 115.00$ off the total of books and microfilm purchased separately.
The fourteen volume Cumulative $S u b$ ject Index to the Monthly Catalog of U.S. Government Publications, $1900-$ 1971 , casebound

The complete run of the Monthly Catalog 1895-1971, on $16 \mathrm{~mm}$ silver halide microfilm.* 750.00

Individual years of the Monthly Catalog or editions of the Decennial Indexes on $16 \mathrm{~mm}$ silver halide microfilm, per reel.*

Send us your free brochure which describes the project in detail and lists prices for alternative microformats.

Name

Address

City 


\section{PUBLICATIONS}

- A series of video tapes explaining Automated Processing, intended for staff, library science students, and university visitors, is available from the Kent State University libraries. Prepared in conjunction with the university's Television Center, Tape One focuses on the impact of automation on an academic library member of the Ohio College Library Center (OCLC).

Tape Two presents the OCLC cataloging system, explains bibliographic searching on the terminals, and demonstrates cataloging based on MARC tapes. Tape Three is a self-teaching device for those who wish to learn to operate the terminals, and is intended as a companion piece to the OCLC manuals now being published.

Cost of Tape One is $\$ 15$. Tape Two is $\$ 35$. The two can be purchased on one reel for $\$ 45$. Cost of Tape Three is yet to be announced. All tapes are $1 / 2$ inch J Standard. Contact Jack W. Scott, Assistant Director, University Libraries, Kent State University, Kent, OH 44242.

- The Urban Archives Center of Temple University libraries has published Private Social Services in Philadelphia: A Survey of the Records. The survey provides information on the history and existing records of 145 agencies. The location, type, quantity, dates, and availability of the records are indicated. There are also references to 130 agencies which merged with or were absorbed by the main listed agencies. There is a subject index. Copies can be obtained from the Urban Archives Center, Paley Library, Temple University, Philadelphia, PA 19122. The price is $\$ 3$, payable to Temple University.

- The proceedings of a seminar on The Changing Role of Directors of University Libraries are now available in 90 -minute cassettes from the Association of College and Research Libraries.

Seven directors of university libraries discuss the implications about the extraordinarily significant article by Arthur M. McAnally and Robert B. Downs, published in College \& Research Libraries, 34:103-25 (March 1973). Leading the discussion was $\mathrm{H}$. William Axford,

Serving libraries for over 25 years for

Building Programs-Reviews of Plans-

Equipment Layouts and Designs LIBRARY MANAGEMENT and BUILDING CONSULTANTS, INC.

Box 58, Evanston, Illinois 60204 $312 / 446 / 8862$ Send for free brochures
University of Oregon, president-elect of ACRL. Participants were: Hugh C. Atkinson, Ohio State University, Richard W. Boss, University of Tennessee, Joseph Dagnese, Purdue University Libraries, Richard Dougherty, University of California/Berkeley, David Laird, University of Arizona and Norman E. Tanis, California State University/Northridge, the president of ACRL.

The cassettes can be purchased from the Association of College and Research Libraries. Send a check for $\$ 6.50$ made payable to the American Library Association to Dr. Beverly P. Lynch, ACRL, 50 E. Huron St., Chicago, IL 60611 .

- Documents submitted for the United Nations Conference on the Human Environment, held in Stockholm in June 1972, the first one calling for worldwide action to protect and improve the human environment, are now available in microform or paper copy and are described in a new catalog available from Unipub, Inc., a Xerox Education Company.

The reports and case studies submitted by nations all over the world, as well as by agencies within the United Nations system and other national and international bodies cover such subjects as: natural resources, air and water pollution, pesticides, noise, human settlements, economic development, population, and public education. For a free copy of the catalog, write: Unipub, Inc., Box 433, Murray Hill Station, New York, NY 10016.

- The University of California, Berkeley, General Library has published a Serials Key Word Index (1973 ed.) listing main entries for 45,741 serial titles under significant words in the entries. This first edition primarily includes currently-received nondocument titles within the General Library system; in all, there are 157,250 listings under 29,911 different terms, each listing including brief holdings, library location, and call number where available.

This computer-produced index was produced from MARC-format serial records, photocomposed in a slab-serif upper-lower case type face, and published in three paperbound volumes. Copies are available, at $\$ 60$ per set, from the Systems Office, Main Library, University of California, Berkeley, CA 94720.

- The University of Washington libraries, Serials Division announces the completion of a new computer-list of serial publications. This list, which is called the Central Serials Record, 1973 , is available for purchase at $\$ 30$ a copy.

The list appears in a single softbound volume of 997 pages. Contained in it are approximately 45,000 entries. Of these, 29,000 represent cur- 
rently-received items, and 10,000 represent stopped items (ceased, cancelled, etc.). The remaining entries are given over to cross-references. Checks should be made payable to University of Washington Libraries, Seattle, WA 98195, in care of Peter Gellatly, Head, Serials Division.

- The University of Michigan announces the availability of a sixty-two-page bibliography entitled, Blacks in America, select holdings of the University of Michigan, Occasional Paper No. 1 compiled by Sara Kelly. For further information contact Sara Kelly, University of Michigan, Dearborn Campus Library, 4901 Evergreen Rd., Dearborn, MI 48128.

- The August 1973 issue of the list of Graduate Library School Programs accredited by the American Library Association is now available. Issued semiannually, the official list gives the name and address of each library school offering an accredited program, the name of the dean or director, and the name of the degree to which the accredited program leads. Library schools offering doctoral and post-master's specialist or certificate programs are so designated on the list. Requests for copies of the list should be addressed to: "Accredited List," American Library Association, 50 E. Huron St., Chicago, IL 60611 .

Japan English Service, Inc., P.O. Box 5, Oami, Shirasato-machi, Sambu-gun, Chiga-ken, Japan, announces the publication of a quarterly annotated bibliography called Inforasia, which will cover new books and nonprint material produced in the English language relating to Asia. It will also highlight news and notes of activities in the field of Asian studies and carry articles by professionals in the areas of librarianship, education, publishing, distribution, and others. The first issue will feature an essay by Professor Takeo Urata of the University of Tokyo on Japanese librarianship.

The purpose of Inforasia is to provide one single and exhaustive source of information on English-language material about Asia for libraries, research institutes, government agencies, individual scholars, and others. Inforasia will be sold at the annual subscription rate of $\$ 15$, including surface postage.

- For the last three years the Library of Congress has recorded the stories, music, and conversation of Burl and Sherman Hammons and their widowed sister, Maggie Hammons Parker. It has now issued an album of two recordings entitled The Hammons Family: A Study of a West Virginia Family's Traditions. The album is the result of a project to research, record, and photograph the history and traditions of a single Appalachian family.

Primarily concerned with presenting traditional music in its human context, the recording includes music, narratives, and lore by members of the Hammons family. Maggie's songs and Burl's and Sherman's banjo and fiddle music alternate with their tales, family stories, and general conversation, making the recording a study of the expressive life of the family.

The two-LP set is accompanied by a thirtysix-page booklet which provides a concise, yet comprehensive history of the origins, migrations, and life-style of the family since its arrival on the Allegheny frontier about 1800. This history, which combines the family's own oral history and extensive documentary research conducted by the editors, leads to general questions and reflections about patterns of settlement and life in Appalachia. Also included in the booklet are transcripts of the recorded stories, songs, and conversations, a bibliography-discography, and a series of historical and contemporary photographs of the family.

The Hammons Family is available by mail for $\$ 10.45$, from the Recording Laboratory, Music Division, Library of Congress, Washington, DC 20540. All orders must be prepaid unless accompanied by an official institutional purchase order. Checks should be made payable to the Music Division, Library of Congress. A free catalog and order form for all LP's in the Library's folk music/folklore series is available from the Recording Laboratory upon request.

- Greenleaf Classics, Inc., has just published a 300-page paperback entitled The $\mathrm{Su}$ preme Court Obscenity Decisions. The work contains the complete text of the Supreme Court's decisions of June 21, 1973, the complete text of the dissents, and the complete text of the rehearing petition, including the Amicus Curiae brief for the American Library Association. The publication is available for $\$ 2.25$ from Greenleaf Classics, Inc., 3511 Camino del Rio, South, San Diego, CA 92120.

- In response to almost constant demand, the editors of Choice are compiling a new edition of "Opening Day Collection." The collection is designed to provide librarians and administrators of new four-year, junior, and community colleges with a basic list of books considered essential in any undergraduate library. The new list, containing over 1,500 titles, includes works in all the categories regularly reviewed in Choice. The collection will appear in four successive issues of Choice, beginning in December 1973. 
Joseph Adna Hill

\section{Women in Gainful Occupations 1870 to 1920. A Study of the Trend of Recent Changes in the Numbers, Occupational Distribution, and Family Relationship of Women Reported in the Census as Following a Gainful Occupation. \\ Washington, 1929. xvi, 416 p. ([U.S.] Bureau of the Census. Census Mono- graphs IX) ISBN 0-384-23273-6 Clothbound, $\$ 17.50$}

This important document records the great historical and sociological changes in the role of women in the United States from 1860 to 1920, and provides a wealth of statistical data available nowhere else.

\section{Charlotte Perkins Gilman}

\section{The Man-Made World}

\section{Or, Our Androcentric Culture}

New York, 1911. 260 p.

ISBN 0-384-18560-6 Clothbound, $\$ 10.00$

An early feminist and one of the most important female thinkers of her day states her case against male supremacy. An essential work for anyone who wishes to understand the roots of the modern women's movement.

\section{Olive Schreiner}

\section{Woman and Labor}

5th ed. New York, 1911. $299 \mathrm{p}$. ISBN 0-384-54280-8 Clothbound, $\$ 10.00$

Hailed by The New York Times in 1911 as one of the most significant studies of the women's movement, this book of essays remains as relevant today and as worthy of serious attention as it was when first published.

\section{From Man to Man Or, Perhaps Only...}

With an introduction by S. C. Cronwright-Schreiner. New York, London, 1927. xxviii, 463 p. ISBN 0-384-54278-6 Clothbound, $\$ 22.50$

\section{Undine}

With an Introduction by S. C. Cronwright-Schreiner. With a New Introduction by Martin Tucker. 1972. xx, Xv, 374 p. Reprint of the New York,

London, 1928 ed. ISBN 0-384-59280-4

Clothbound, $\$ 15.00$

These two novels by Olive Schreiner, long recognized as the first major South African writer, are powerful.explorations of the experience of young women in a world dominated by men. 